\title{
Online sources for research in arts, history, and culture
}

$\mathbf{T}^{\mathrm{t}}$ he population in the United States is changing. According to the Pew Research Center the nation's Hispanic population has grown 57\% since 2000. This diversity is reflected in academia. As a result, there is increasing interest in Latin American and Caribbean art, history, and culture. This introductory guide is one of several sources preparing librarians to support scholars in non-Western areas.

A product of Western influence within the larger African diaspora, Jamaican art is grouped within non-Western art tradition and exists under the umbrella of Latin American art. Like many of the Caribbean islands, Jamaica is a popular tourist destination. However Jamaican art provides a window into the often turbulent history of the country that many tourists don't see.

There are a number of websites that shed light on Jamaican art, history, and culture. While not comprehensive, this guide identifies museums and collections in the United States and the Caribbean, and spotlights a number of resources that provide primary and secondary resources to support research into the country, such as histories, images, and maps.

To understand this rich and vibrant history, researchers may wish to focus on three areas: review the primary documents and map of the three landmark events in Jamaican history: the Sam Shepard Rebellion/Baptist War, the Morant Bay Rebellion, and the Labour Riots; peruse the images of the artifacts from the Taínos, the native people that inhabited the island before Europeans; and learn the definitions and history behind the Jamaican language, Patwah.

\section{Encyclopedia and dictionary}

- Jamaican Patwah. While Jamaicans write in English, many speak Jamaican Patwah or Jamaican Creole, an English-based language with West African influence brought over by 17 th-century slaves to Jamaica. There are many print dictionaries, but this crowdsourced online dictionary can help one begin to understand the spoken word, complete with slang terms, proverbs, idioms, jargon, and figurative usages. This site has audio pronunciations, and the identified word is used in a sentence in Patwah accompanied by English translation. Access: http://www. jamaicanpatwah.com.

- Wikipedia. This openly editable online encyclopedia is updated regularly and has a staff of editors that check articles for verification. Wikipedia boasts more than 82,000 contributors on more than $38,000,000$ articles in 290 languages. Entries on Jamaica, Jamaican culture, and Jamaican art are robust and provide a wealth of information on the art and culture of the island. Access: https:// www.wikipedia.org/.

\section{Historical}

- Jamaican National Heritage Trust. Committed to sharing and protecting the island's cultural heritage, this government resource provides descriptive historical narratives of Jamaican history from the Pre-

Kai Alexis Smith is visiting assistant librarian at the University of Notre Dame, email: kaialexis@gmail.com

(C) 2016 Kai Alexis Smith 
Columbian, Columbian/Spanish, English, and Independence periods. An account of how the government is set up helps to provide a framework for understanding the political issues represented in many Jamaican artists' works. Basic PDFs inform researchers of the Taíno origins, religion, society, and way of life. Fast facts about the geography, people, and political parties are provided that give a broad overview of Jamaica. In addition, several articles discuss the influences on Jamaican folk tradition, the differences between the Arawak and Taíno, and the importance of caves to the culture, including a list of petroglyph and pictographic sites. Access: http://www.jnht.com/.

- Museum of History and Ethnography, Institute of Jamaica. With more than 17,000 historic, ethnographic, and archaeological artifacts, this authoritative website is the repository for Jamaica's National Collection. Within the collection are artifacts from the Taíno culture. While only a handful of the collection is online, it does pair images of objects with brief narratives explaining their significance. A sampling of other collections are also featured on the website. Access: http://museums-ioj.org.jm/?p=2957.

- The National Library of Jamaica. The library has a number of databases, including the Jamaican Personalities database, Jamaican proverbs, and the free online digital archive. This digital collection combines books,

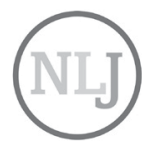

NATIONAL

LIBRARY OF JAMAICA ments, maps,

tographs related to three landmark events in Jamaica's history: the Sam Sharpe Rebellion/ Baptist War (1831), the Morant Bay Rebellion (1865), and the Labour Riots (1938). The scanned documents and images provided in these collections are not high quality, but are sufficient to read. In addition, monthly usage statistics are offered, dating back to 2009. Access: http://www.nlj.gov.jm/.

\section{Statistics}

- Government of Jamaica Statistics.
This government website provides statistics on population, the economy, labor market and earnings, the environment, and more. Data visualization is available for 2001 data, and newer data can be ordered from the Geographic Services Unit. Access: http:// statinja.gov.jm/.

- United States Census Bureau Foreign Trade in Goods with Jamaica. The U.S. government keeps track of current monthly imports and exports between the countries dating back to 1985. Access: https://www. census.gov/foreign-trade/balance/c2410.html.

\section{Periodicals and journals}

- African Caribbean Institute of Jamaica (IOJ)'s Jamaica Memory Bank Publications. As early as the 1970s, this IOJ unit was responsible for documenting and sharing information on the impact and presence of the African diaspora in Jamaica and throughout the Caribbean. While the publications can not be accessed on the official website, the link leads you to the list of publications that can be found through WorldCat. Access: https://www.worldcat.org /search?qt=worldcat_org_all\&q=African +Caribbean+Institute+ + +Jamaica.

- ARC Magazine. Artists Nadia Huggins and Holly Bynoe publish this biennial Caribbean arts culture magazine. While this periodical is still in its infancy, it features works from the emerging and established artist. Access: http://arcthemagazine.com/ arc/home/.

- Institute of Jamaica's Jamaica Journal. This academic journal is published quarterly and produces scholarly articles on art, history, music, and Jamaican culture. Access: http://209.238.103.104/ jj/ioj_wp/.

- The Gleaner. Founded in 1843, this Jamaican-based newspaper provides the latest happenings in the country six days a week. There is a Sunday version of the paper called the Sunday Gleaner. Aside from Jamaica, it is published in the United Kingdom, Canada, and the United States. Access: http:// jamaica-gleaner.com/.

- Jamaica Observer. This daily news 
outlet was created as a competitor to The Gleaner in 1993. This resource provides news from a different perspective than its competitor. Access: http://www.jamaicaobserver. $\mathrm{com} /$.

\section{Indexes}

- Black Studies Center. This monthly updated, cross-searchable database combines Schomburg Studies on the Black Experience, International Index of Black Periodicals, and the Chicago Defender newspaper. The scope ranges from 1827 to the present and offers full text of scholarly essays, magazines, and historical newspapers. This is a subscription-only resource. Access: http://bsc.chadwyck.com/.

- Hispanic American Periodicals Index (HAPI). HAPI, is an authoritative source for international information on Central and South America, Mexico, Brazil, the Caribbean basin, the United States-Mexico border region, and Hispanics/Latinos in the United States. The database contains complete bibliographic citations to articles, book reviews (through 2001), documents, original literary works, and other materials. Regularly updated, HAPI contains more than 300,000 citations. Subject searching must be done in English, however, there is a feature that translates subject headings into Spanish or Portuguese. The collection starts in 1970. While all sources don't have full text links, many do. It is a wonderful resource to update oneself on the history of the Caribbean and Jamaica through journals and periodicals. The citations provide a good entry research. This is a subscription-only resource. Access: http://hapi.ucla.edu/.

\section{Museums and galleries}

- Harmony Hall Gallery. Located in Ocho Rios, Jamaica, this gallery has been a hub for contemporary local (intuitive) and international artists since 1980. Most artists concentrate in the medium of painting and fiber arts. Artist biographies are brief and focus on education and awards, but images accompany each entry along with links to the artist's website, if available. All images featured on the website are also for sale. Access: http:// www.harmonyhall.com/Gallery/artists.php.

- Institute of Jamaica (IOJ) Virtual Museum. Founded in 1879, the IOJ Virtual Museum is a significant cultural, artistic, and scientific organization. Created in 2012, the Virtual Museum is intended to replicate the "brick and mortar" IOJ museum and provides multimedia information on exhibits in the

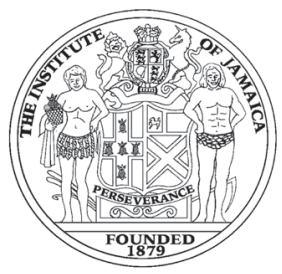
museum. The website has digital replicas of temporary physical exhibitions, virtual tours, audio summaries, curator talks, and narratives on artifacts, artwork, and topics featured in exhibitions. Access: http:// vm.instituteofjamaica.org.jm/portfolio-page/.

- The Mutual Life Gallery. Established in Kingston, Jamaica, in 1975, this gallery promoted contemporary Jamaican artists on the island and internationally. The website provides entries on select artists. Included are biographies focused on education, career accomplishments, artists' statements, and some exhibition lists. The gallery closed in 2013, but the pages can be viewed on the Wayback Machine website. Access: http://web.archive. org/web/20131025165801/ and http://www. mutualgallery.com/.

- National Gallery of Jamaica. Since 1974, the National Gallery of Jamaica has been the main public repository of early, modern, and contemporary Jamaican art along with smaller Caribbean and international holdings. It is the largest public art gallery in the Anglo Caribbean region. While their collections are not online, the blog is very active with current events, exhibitions, and even videos of artists' lectures. Access: http://natgalja.org.jm/.

- Pan American Arts Project. A Miamibased gallery created the Pan American Arts Project, which promotes international artists of distinction with a focus on art from Europe and the Americas. Users can search by country and alphabetically. More than 30 Jamaican artists are shown, most displaying 
a biography, exhibitions and awards, and a sampling of their work. Access: http:// panamericanart.com/.

\section{Arts web resources}

- Art Jamaica. Enthusiastic collector Theresa Roberts displays her vast collection of Jamaican artists' work with the goal of promoting Jamaican artists internationally. The images are of sufficient resolution for online viewing. An important feature of this collection is that all of the exhibition catalogs from Art Jamaica shows have been scanned and uploaded to the website for viewing. A video about the organization's exhibition at the Murray Edwards College in Cambridge, England, talks about the importance of Jamaican artists women. This website can also be read in Spanish. Access: http://www.art-jamaica.org/.

- Black Circle Gallery. Also founded by the longtime supporter of Jamaican arts Theresa Roberts, this gallery shows artists from other countries underrepresented in Europe. The sleek website features artists biographies with a small selection of the images by the artists. Click on the thumbnail for larger images. Access: http:// blackcirclegallery.com/.

- Oneika Russell's ART: Jamaica. Started in 2006 and ending in 2016, this blog

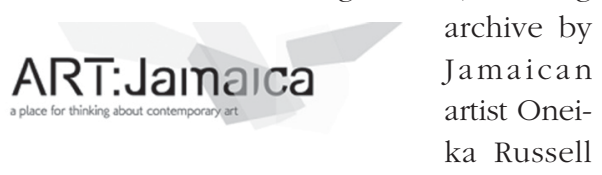

discussed contemporary Jamaican and international art. Access: http://artjamaica. blogspot.com/.

- Peabody Essex Museum's Island Thresholds: Contemporary Art from the Caribbean. While this exhibition is dated, the content is still very relevant. This was

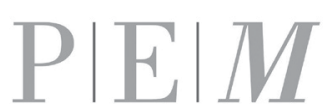

Peabody Essex Museum a collaboration of several artists from different islands led by the Peabody Essex

Museum. One student from the Dominican Republic got the opportunity to interview these accomplished artists. Her questions and responses are on this virtual exhibition in audio format. A sampling of each artist's work is available, along with several accompanying audio commentary. Some of the artists don't speak English, so written English translations are featured with the audio. The website can be experienced in English, Spanish, or French. Access: http://www.pem.org/sites/island/.

- Petrine Archer-Straw. This authoritative blog was written by Caribbean art historian Petrine Archer-Straw, who passed away in 2012. It includes her biography, honors, and awards, but the most interesting part of her website is the Diaspora Dialogs blog where she critiqued and discussed both historical and modern topics in Caribbean art history. While the Caribbean Artist A-Z write ups merely give the researcher a taste of the artist's concepts and education, the database is extensive and includes over a hundred artists. Some entries include links to view featured images of the artist's work. Access: http:// www.petrinearcher.com/.

- University of Florida's About Face: Revisiting Jamaica's First Exhibition in Europe. This digital collection at the University of Florida provides primary sources of the first Jamaican art exhibit in Europe. One may learn about the participating artists, view the exhibition catalog, and read reviews. Also, information about pop culture provides additional historical context for researchers. Access: http://exhibits.uflib.ufl.edu/aboutface/.

\section{Online databases}

- Digital Library of the Caribbean. A collaborative effort between multiple international institutions in the United States, South America, and the Caribbean, this free digital library provides the user access to digitized versions of Caribbean cultural, historical, and research materials currently held in archives, libraries, and private collections in multiple languages. Collections of interest are the dLOC: Caribbean Map Collection and the Caribbean Newspaper Digital Library. Access: http://www.dloc.com/.

(continues on page 257) 
sessing the library's relationship to student learning and outcomes.

- Joan E. Beaudoin. "Describing Images: A Case Study of Visual Literacy among Library and Information Science Students." Abstract: This paper reports on a study that examined the development of pedagogical methods for increasing the visual literacy skills of a group of library and information science students. Through a series of three assignments, students were asked to provide descriptive information for a set of historical photographs and record reflections of their experiences via blog posts. The three separate versions of the image descriptions submitted by the students were analyzed to discern changes using descriptive statistics, and their blog posts were examined to identify recurrent themes using the constant comparative method. Findings associated with the image descriptions indicate that students' skill in describing the photographs show a modest increase across the three versions. Analysis of the blog postings revealed an overarching theme of frustration associated with the experience of developing image descriptions among the students. The underlying reasons for their frustrations are examined, and suggestions are provided for further increasing students' abilities to describe images.

\section{Online forum on Assessment in Action recording available}

Following the release of the special issue on Assessment in Action (AiA) in March, CERL sponsored an online forum with AiA authors from Anne Arundel Community College and
Grinnell College on March 24, 2016. The recording of this session, attended live by almost 150 participants, is now available at: http://crl.acrl.org/site/misc/fora.xhtml.

\section{One final note}

This will be my final CERL Spotlight column, as I hand the reins over to our incoming editor, Wendi Arant Kaspar (Texas A\&M University). We created the Spotlight to promote continuing engagement among the journal and its readers once we made the transition to e-only publishing, and I have been pleased to see it routinely found among the most accessed features of each issue of the News in which it has appeared. I look forward to continuing to see new "spotlight" features in the coming issues as I transition from editor back to "engaged reader." Thanks to ACRL's David Free and Dawn Mueller for their support of the journal (and the column), to the members of the $C \& R L$ Editorial Board for their leadership and assistance in the design of these columns, and to the $C G R L$ authors and readers who gave us something to write about.

\section{Notes}

1. Steven J. Bell, "Keeping Up with . . . Learning Analytics," accessed April 11, 2016, www.ala.org/acrl/publications/keeping_up _with/learning_analytics.

2. Association of College \& Research Libraries, "ACRL e-Learning Webcast Series: Learning Analytics-Strategies for Optimizing Student Data on Your Campus," accessed April 11, 2016, www.ala.org/acrl /learninganalytics. n

("Jamaica," continues from page 254)

- The Getty Research Institute's Union List of Artist Names. This free structured vocabulary database makes searching artists, including Jamaican artists, incredibly easy. This annually updated hierarchical database is set up in list form and like a thesaurus. This database lists not only biographical informa- tion about artists, but includes lists of people related to them (spouses, children, and teachers), and links to records of those people, links to information on the cities where the artist was born and died, and sources and contributions. Access: http://www.getty.edu/ research/tools/vocabularies/ulan/. $\boldsymbol{n}$ 